Research Article

\title{
Growth and Development of Tristaniopsis merguensis Seedling Inoculated by Natural Ectomycorrhiza
}

\author{
Triadiati Triadiati*, Anastastia Raditya Hidayanti, Nampiah Sukarno \\ Department of Biology, Faculty of Mathematics and Natural Sciences, IPB University, 16680 Bogor, Indonesia
}

Article history:

Submission October 2019

Revised December 2019

Accepted January 2020

*Corresponding author:

E-mail: adiatiipb@gmail.com

\begin{abstract}
Tristaniopsis merguensis (pelawan tree, Indonesia) is a potential plant as a firewood, host for edible fungi, and nectar from the flower produce bitter honey. The existence of T. merguensis in the forest is important because the fungi grow under the tree, particularly in the above of the roots. However, it has not cultivated and conserved optimally due to slow growth and lack of information about the cultivation. Information about how to grow the T. merguensis seeds is very limited; therefore, research in growth and development of T. merguensis seedling was important. The aims of this study were to determine the appropriate planting medium for T. merguensis seed germination and to stimulate growth and development of T. merguensis seedling by using its fungi. Status of T. merguensis fungi was studied by analyzing root morphology. Fungi isolation was carried out from colonized root and fungi fruit body. The stimulated growth of T. merguensis seedling was carried out by using fungi isolated from colonization root in laboratory scale, as well as treated at a different phosphate concentration. The result showed that $T$. merguensis was associated with ectomycorrhizal fungi. Planting medium consists of sawdust and T. merguensis fine root resulted the highest percentage of germination. Seedlings were treated with ectomycorrhizal fungi grew better than without ectomycorrhizal fungi. The treatment of ectomycorrhizal fungi and phosphate $25 \%$ showed the highest growth rate.
\end{abstract}

Keywords: Ectomycorrhizal fungi, Sawdust, Heimiporus fungi, Tristaniopsis

\section{Introduction}

In Indonesia, Tristaniopsis merguensis (Myrtaceae), known as the Pelawan trees is a valuable tree have a strong and dy wood for firewood, furniture, build houses, and timber stands. Local people using the T. merguensis leaves for tea. The leaves have alkaloids, phenols, tannins, and flavonoids as antioxidants [1]. In addition, these trees produce bitter honey from flowers and edible fungi (Heimiporus sp) where growing under the tree canopy and above its roots. These fungi grow only at the beginning of the rainy season, once a year. The color of fungi is red when fresh and expensive in local market and for export.

T.merguensis grows in evergreen forests at low altitudes and on ridges up to 1,000 m altitude. It is a tree up to $30 \mathrm{~m}$ tall, with its smooth, lightbrown, trunk bark flaking off in large, spiral, scroll-like pieces. The distribution of these plant is in Andaman Islands, Mergui Archipelago, Cambodia, Vietnam, Peninsular Malaysia, Singapore, Nepal, and Indonesia, especially found in Kalimantan [2, 3, 4]. T. merguensis tree in Indonesia also grows in the Province of Kepulauan Bangka Belitung. This species has been recognized as one of the key species for biodiversity sustainability in Kepulauan Bangka Belitung, since the T. merguensis tree can guarantee the growth of the fungi and as a feed trees by honey-bee [5]. Naturally, $T$. merguensis tree grows in the forest. Thus, T. merguensis is a tree with high economic value; however, it is not cultivated and conserved optimally due to slow growth and lack of information about cultivation. Currently, T. merguensis trees are rarely found in the Province of Kepulauan Bangka Belitung due to excessive exploitation. It is impor- 
Table 1. Percentage of germination, plant height, and number of leaves of T. merguensis seedlings (8 WAP)

\begin{tabular}{clccc}
\hline \multirow{2}{*}{ No. of Tray } & \multicolumn{1}{c}{ Treatments } & $\begin{array}{c}\text { Germination } \\
(\%)\end{array}$ & $\begin{array}{c}\text { Plant height } \\
(\mathrm{cm})\end{array}$ & $\begin{array}{c}\text { Number of leaves } \\
\text { (individual) }\end{array}$ \\
\hline 1 & $\begin{array}{l}\text { Zeolite + T. merguensis } \\
\text { fine roots }\end{array}$ & $7^{\mathrm{c}}$ & $3.5^{\mathrm{a}}$ & $4^{\mathrm{a}}$ \\
2 & Coco peat + T. merguensis fine roots & $23^{\mathrm{b}}$ & $3.2^{\mathrm{a}}$ & $5^{\mathrm{a}}$ \\
3 & Husk charcoal + & $38^{\mathrm{b}}$ & $3.8^{\mathrm{a}}$ & $6^{\mathrm{a}}$ \\
\\
& T. merguensis fine roots & & & $6^{\mathrm{a}}$ \\
5 & Sawdust + T. merguensis fine roots & $64^{\mathrm{a}}$ & $4.0^{\mathrm{a}}$ & 0 \\
6 & Sand : soil (1:1) & 0 & 0 & 0 \\
\hline
\end{tabular}

The data was followed by the same letter in the same column indicate not significantly different (Duncan-test; $\alpha=5 \%)$

tant that this tree is retained to grow naturally for the purpose of fungi growth and bitter honey. Therefore, there is an important need to develop ex situ propagation to support replanting in natural habitats. On the other side, the study of T. merguensis tree propagation is very limited.

Myrtaceae is a family of plant that forming symbiotic relationships with ectomycorrhizal fungi [6]. Tristaniopsis obovata was reported to form a symbiotic association with Cenococcum geophilum ectomychorriza [7]. Because T. merguensis is included in Myrtaceae, we hypothesized that T. merguensis also has an opportunity to symbiosis with ectomycorrhizal. However, it is not known yet which fungi can form a symbiotic association with T. merguensis trees. Usually, the local people took $T$. merguensis seedlings from the forest for replanting. Until now, it is difficult to grow the $T$. merguensis seeds out-side the natural habitat (ex-situ). Therefore, it is important to find a method for germination and growth of $T$. merguensis seed ex-situ to support the sustainability diversity of $T$. merguensis biodiversity in the Province of Kepulauan Bangka Belitung. The purposes of this study are to discover the optimal media for germinating and cultivate of $T$. merguensis and optimizing the growth and development of seedlings by using natural ectomycorrhiza.

\section{Material and Methods Study Area}

Materials used in this research were $T$. merguensis seeds, zeolite, coco peat, sand, husk charcoal, sawdust, soil, Johnson solution [8] and a soilmycelium system (fine root and local inoculum from $T$. merguensis forest) taken from T. merguen- sis forest in Center Bangka Tengah District, Kepulauan Bangka Belitung Province where located at 2¹9'18" S and 106 09'51" E.

\section{Bioassay of symbiosis.}

$T$. merguensis seeds were surface sterilized by soaking in $70 \%$ alcohol (v/v) for one minute and then rinsed with sterile aquadest five times. $T$. merguensis seed was dipped in $0.05 \%$ chlorox (v/v) for one minute and rinsed with sterile aquadest five times. Furthermore, sterilized seeds germinated in sterile zeolite media. Seedling of $T$. merguensis is transferred to pots with sterile zeolite and treated with top soil containing ectomycorrhizal mycelium collected from $T$. merguensis forest and Johnson solution. Johnson solution was used as a phosphate treatment. The plants without inoculation received phosphate treatments of $0 \%$ (P0), 25\% (P25-k), 50\% (P50-k), and 75\% (P75$\mathrm{k}$ ), whereas the inoculated plants received phosphate treatments of 25\% (P25-i), 50\% (P50-i), and 75\% (P75-i), respectively. Each treatment was carried out in four replicates. Parameters observed were the number of leaves and plant height weekly until 20 weeks after planting (WAP). Harvest of the root was carried out at 20 WAP (week after planted) for observation of ectomycorrhizal colonization.

\section{Germination of T. merguensis seed}

Seeds were collected from $T$. merguensis trees where grown in the forest. About 1,000 of T. merguensis seeds were spread in a tray with planting medium. The composition of planting medium consists of three layers. Seeds were spread on the surface of second layer of planting medium. The treatments of planting medium were shown in Ta- 
ble 1 . The design of this research was completely randomized design with five replicates. All treatments were placed under the plastic lid for 2 months until the seedlings have 4 leaves. The humidity of planting medium was maintained about $70-80 \%$ by watering every day with sprayer. The parameters measured were percen-tage of germination, plant height, and number of leaves during 8 WAP.

\section{Data analysis}

All data were analyzed using general linear models (GLMs). All post hoc tests were carried out using DMRT. The standard level of significance was $\mathrm{p}<0.05$. All analyses were done using SPSS 20.0 software.

\section{Results and Discussion \\ Germination of T. merguensis seeds}

The $T$. merguensis seeds were spread in tray number 1 - 4 germinated a week after spreading, whereas no germination in tray number 5 - 7 (Table 1). Tray number 1 to 4 contained $T$. merguensis fine roots, on the other side, tray 5 to $7 \mathrm{did}$ not contain fine roots. The tray no. 4 had the highest percentage of germination.

To analyze the $T$. merguensis seedlings growth rate we used treatments of natural ectomycorrhiza mycelium (isolated from T. merguensis roots in the forest) and different phosphate concentrations (Johnson solution) in the laboratory. Figure 1 shows that all treatments have a quite similar growth rate pattern during $19 \mathrm{WAP}$, but treatment of phosphate $25 \%$ with inoculation (P25-i) has the best growth indicated by plant height. On the other side, leaves number of controls was significantly different $(\mathrm{p}<0.05$ ) with the inoculation and phosphate concentrations treatments during 19 WAP (Figure 2). The number of leaves and plant height of $T$. merguensis seedlings were influenced $(\mathrm{p}<$ 0.05 ) by interaction between ectomycorrhizal mycelium and different phosphate concentrations treatments. The leaves number and plant height of T. merguensis seedlings treated by phosphate 75 $\%$ with inoculation (P75-i) have the highest than others at 19 WAP (Table 2).

\section{Symbiotic bioassay of T. merguensis seeds}

Symbiotic bioassay of $T$. merguensis seeds was conducted to prove that symbiotic fungi affected $T$. merguensis seedlings growth. The plant

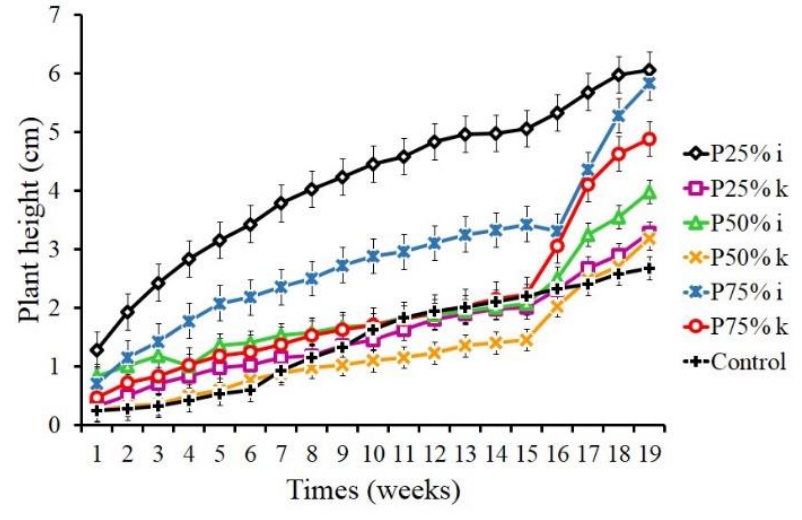

Figure 1. Growth rate of T. merguensis seedlings using plant height treated by ectomycorrhizal mycelium and different phosphate concentrations (Johnson solution) in laboratory

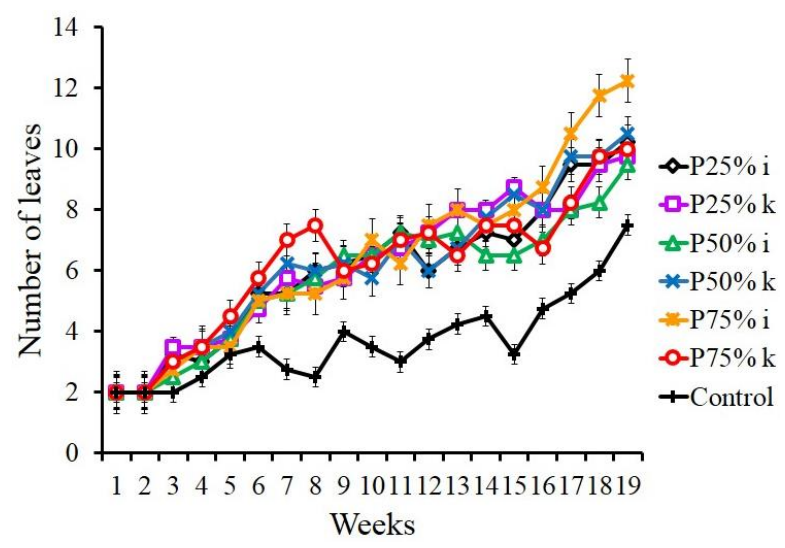

Figure 2. Leaves growth of $T$. merguensis seedlings treated by ectomycorrhizal mycelium and different phosphate concentrations (Johnson solution) in laboratory

height of $T$. merguensis seedlings treated by phosphate and without inoculation was not significantly different from control. The plant height of $T$. merguensis seedlings was not influenced by treatments of phosphate without inoculation (Figure 1 and 3). On the other side, the plant height of P25-i was higher than that of P50-i and P75-i (Figures 1 and 4). The number of leaves from $T$. merguensis seedling of all phosphate and with or without inoculation treatments were not significantly different, but significantly different from control (Figure 2).

The leave color of $T$. merguensis seedlings was treated by ectomycorrhizal fungi with phosphate greener than that of control. The treatment of P25\% with ectomycorrhizal fungi i noculation P25-i) exhibited dark green (scale of 5-6) than all the phosphate treatments (Table 3). 
Table 2. Number of leaves and plant height of $T$. merguensis seedlings treated by ectomycorrhizal mycelium and different phosphate concentrations (Johnson solution) in the laboratory (19 WAP)

\begin{tabular}{cccc}
\hline Treatment of phosphate & Treatment of inoculation & Number of leaves & Plant height (cm) \\
\hline Control & & $3^{\mathrm{c}}$ & $2.7^{\mathrm{c}}$ \\
& without inoculation (k) & $10^{\mathrm{b}}$ & $3.3^{\mathrm{bc}}$ \\
P25\% & with inoculation (i) & $10^{\mathrm{b}}$ & $6.1 \mathrm{a}$ \\
& without inoculation (k) & $10^{\mathrm{b}}$ & $3.2^{\mathrm{bc}}$ \\
\multirow{2}{*}{ P75\% } & with inoculation (i) & $11^{\mathrm{b}}$ & $4.0^{\mathrm{bc}}$ \\
& without inoculation (k) & $10^{\mathrm{b}}$ & $4.9^{\mathrm{b}}$ \\
& with inoculation (i) & $13^{\mathrm{b}}$ & $5.8^{\mathrm{a}}$ \\
\hline
\end{tabular}

The data was followed by the same letter in the same column indicate not significantly different (Duncan-test; $\alpha=5 \%)$

Table 3. Leaves color based on color chart* of T. merguensis (20 WAP)

\begin{tabular}{cccc}
\hline Treatment of phosphate & Treatment of inoculation & $\begin{array}{c}\text { Leaves color scale } \\
\text { based on color chart * }\end{array}$ & Note \\
\hline Control & - & 2 to 3 & Yellow to green yellowish \\
P25\% & without inoculation (k) & 4 to 5 & Green to dark green \\
& with inoculation (i) & 5 to 6 & Dark green to very dark green \\
P50\% & without inoculation (k) & 4 & Green \\
& with inoculation (i) & 3 to 4 & Green yellowish to light green \\
P75\% & without inoculation (k) & 3 to 4 & Green yellowish to light green \\
& with inoculation (i) & 3 & Green yellowish \\
\hline
\end{tabular}

*Leaf Color Chart from IRRI (scale 1-6)

The root of seedlings was treated without inoculation (k) did not form a symbiosis with ectomycorrhizal mycelium. On the other side, the seedlings were treated with inoculation and $25 \%$ phosphate (P25-i) formed colonization. Treatment of inoculation with $50 \%$ phosphate (P50-i) and $75 \%$ phosphate (P75-i) did not have root colonization (Table 4).

The root of T. merguensis treated with ectomycorrhizal fungi has shown in initial colonization from mycelium structures surrounding the outer surface of the root (Figure 5).

The symbiotic between the T. merguensis and the fungus was analyzed using $T$. merguensis growth parameters. In this study, the plant height of the treatment $25 \%$ phosphate with inoculation (P25-i) was higher than that of the treatment $25 \%$ phosphate without inoculation (P25-k) (Table 2). The increased plant height of the $25 \%$ phosphate treatment with inoculation (P25\%-i) may have been influenced by successful of symbiosis between ectomycorrhiza and seedling roots of $T$. merguensis. This data supported by observations on the roots of $T$. merguensis inoculated by ectomycorrhizal fungi. The other study reported that the plant height of Populus hopeiensis (myco-rrhizal plants) was significantly stimulated with ectomycorrhiza (Boletus edulis) inoculation [9]. The root of $T$. merguensis which was colonized with ectomycorrhiza have hyphal growth on the outer surface of the root. This result is consistent with research conducted by Taylor and Alexander; Perrier et al. that colonization of plant roots by ectomycorrhiza was characterized by existing hypha in surface of root until penetrating the root epidermis $[10,11]$. Therefore, the height of $T$. merguensis seedlings was inoculated with a soil-mycelium system was higher than that of seedlings without inoculated. The mutuality symbiosis between ectomycorrhizal fungi with plant's roots can increase the height of the host plant [12]. Mycorrhizal fungi regulate nutrient flow between the soil and plants [10], it helps in the absorption of the relatively immobile ions in soils such as phosphate, copper, and zinc [13]. This mutualistic symbiosis provides the fungi with relatively constant and direct access to carbohydrates, such as glucose and sucrose $[14,15]$. The carbohydrates are translocated from leaves to root tissue and on to the plant's host. In return, the plant gains the bene- 
Table 4. Colonization evaluation of T. merguensis seedling treated by phosphate (Johnson solution) and ectomycorrhiza inoculation for 5 months.

\begin{tabular}{cccc}
\hline Treatment of phosphate & Treatment of inoculation & Colonization & Response \\
\hline Control & without inoculation $(\mathrm{k})$ & no colonization & - (neg.) \\
P25\% & with inoculation (i) & colonization & - (neg.) \\
& without inoculation $(\mathrm{k})$ & no colonization & - (neg.) \\
P50\% & with inoculation (i) & no colonization & - (neg.) \\
& without inoculation $(\mathrm{k})$ & no colonization & - (neg.) \\
P75\% & with inoculation $(\mathrm{i})$ & no colonization & - (neg.) \\
\hline
\end{tabular}

fits of the mycelium's higher absorptive capacity for water and mineral nutrients due to the comparatively large surface area of mycelium/root ratio, thus improving the plant's mineral absorption capabilities [16]. Most plants consist of two P-uptake pathways, namely the direct root P-uptake pathway and the mycorrhizal fungi P uptake pathway [17]. Most P fertilizers are immobilized in soils because $\mathrm{P}$ is strongly adsorbed to iron and aluminium cations at low soil $\mathrm{pH}$ and to calcium at high soil pH $[18,19]$. Thus, root architectural features and the growth of mycorrhizal hyphae are important for maximizing the acquisition of $\mathrm{P}$ because the root and mycorrhizal systems with a relatively high surface area are able to effectively use a given volume of soil [20]. The mycelium of the ectomycorrhizal fungi can access these phosphorus sources and make them available for the host plants. Phosphate ions are required by the host plants to stimulate early growth and development and root formation [21].

In this study, the $T$. merguensis fine roots in planting media stimulated the germination of $T$. merguensis seeds. When compared with the treatments without $T$. merguensis fine roots in planting medium, it was assumed that fine roots of T. merguensis affected the germination of $T$. merguensis seeds. The T. merguensis fine roots is thought to be symbiotic with fungi forming ectomycorrhiza. Symbiotic association between plant roots and certain fungi is referred to as mycorrhiza [22].

Planting medium consisting of sawdust gave the best result because it can retain planting medium moisture which is suitable for T. merguensis seed germination. Moisture planting media are needed in the early stages of germination for seedling growth [23]. Moreover, sawdust is organic matter consists of carbon organic from cellulose, nitrogen, potassium, and phosphate. These nutri- ent mineral in sawdust are important for the seedling of $T$. merguensis growth.

Roots of seedling were treated without inoculation did not form a symbiosis with ectomycorrhizal fungi. On the other side, seedlings were treated with inoculation and P25\% (P25-i) formed colonization. The treatment of inoculation and P50\% (P50-i) and P75\% (P75-i) did not produce root colonization. There was no colonization in the treatment of $\mathrm{P} 50 \%$ (P50-i) and $\mathrm{P} 75 \%$ (P75-i) was due to seedling were harvested too early (20 WAP). Therefore, there was no penetration yet of hyphae into the root epidermis, which subsequently could form the structure of colonization. Initial penetration of hyphae ectomycorrhizal Tricholoma sp. to the root epidermis of Pinus densiflora in greenhouse was found about 6 months after inoculated. At this stage, no formation of colonizing roots structures since hypha only penetrated upper layer of epidermis roots [24].

Seedling height treated with inoculation and P25\% (P25-i) differed significantly from treatment without inoculation and P25\% (P25-k). It is suspected that inoculation and $\mathrm{P} 25 \%$ treatment (P25\%-i) caused symbiotic formation between ectomycorrhiza with T. merguensis. Mycorrhizal fungi are able to form symbiotic relationship with the host plants when it's grown in soil that contains low nutrients, thus, the host plant can grow well, even it planted in poor soil. The host plant will develop resistance to the fungal penetration when the concentration of phosphate in soil is too high, due to high soil phosphate levels have been found to be detrimental for the symbiotic association of mycorrhizal fungi with plants. The lower content of soil phosphate can increase the activity of fungi in the establishment of mycorrhizal symbiosis which can provide increased growth and development of the host plant [25]. 


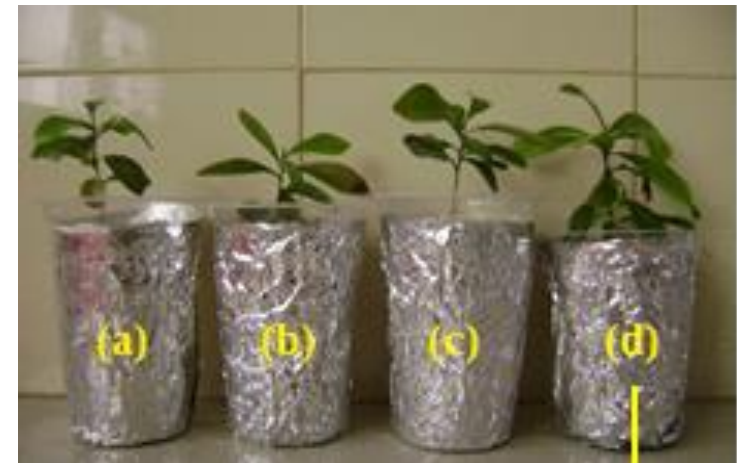

Figure 3. Plant height of T. merguensis seedlings. (a) Seedling of control plant and without inoculation (b) with phosphate 25\% (P25-i), (c) phos-phate $50 \%$ (P50-i), (d) phosphate $\mathrm{P} 75 \%$ (P75-i). Scale bar $=5 \mathrm{~cm}$

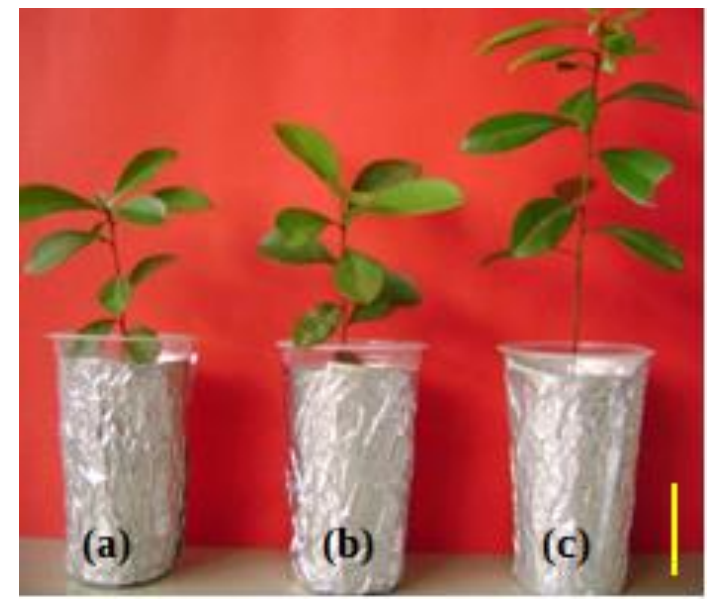

Figure 4. Plant height of $T$. merguensis seedlings. Seedling of T. merguensis treated with ectomycorrhiza fungi inoculation and Johnson solution contained (a) phosphate 50\% (P50i), (b) phosphate 75\% (P75-i), and (c) phosphate 25\% (P25-i) in 5 MAP. Scale bar $=5$ $\mathrm{cm}$.

The leaves number in all treatment was not significantly different until 20 WAP. However, although the leaves' number did not differ, they have different leaves color. Leaves of seedlings treated with inoculation and P25\% (P25-i) has greener than the other treatments. On this treatment, the phosphate nutrient that play a role in the chlorophyll biosynthesis which affects photosynthesis. This result is consistent with Curtis and Clark which stated that the phoshate has an effect on plant growth and development through photosynthesis [26].

Figure 5 shows that roots of $T$. merguensis which inoculated by ectomycorrhizal mycelium

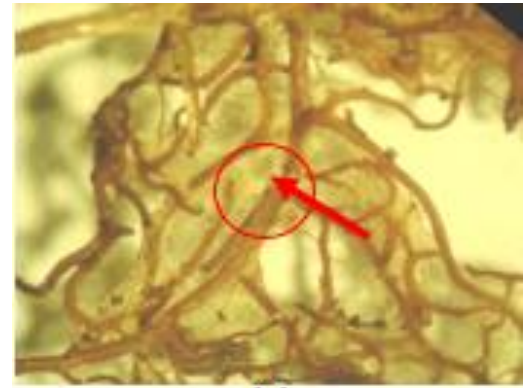

(a)

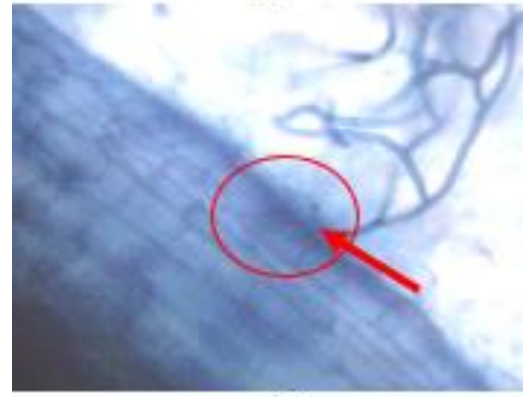

(b)

Figure 5. Root structure of $T$. merguensis seedling with fungi inoculation in the laboratory experiments. Initially structure (a) $T$. merguensis root after fungi inoculation, (b) ectomycorrhiza hyphae in outer surface of root

form colonization with mycorrhizas fungi. This data proves that the root of T. merguensis need ectomycorrhizal fungi since the beginning of growth. This study is supported by the previous studied that T. guillainii, T. calobuxus, and T. whiteana have mycorrhizal symbioses with arbuscular mycorrhizas fungi [11, 27]. It can be assumed that $T$. merguensis tree has a similar symbiotic association between ectomycorrhiza with others Tristaniopsis.

\section{Conclusion}

From pesent study it is concluded that $T$. merguensis is able to form a symbiosis with ectomycorrhizal fungi. Inoculation treatment with P25\% (P25-i) improves plant growth and promote the ectomycorrhizal colonization. It was observed that formation of mycorrhizal colonization beginning at 20 WAP. Fine roots (soil-mycelium system) mixed with planting medium especially sawdust was important for the purpose of stimulating seed germination and seedling growth of $T$. merguensis. 


\section{Acknowledgment}

We thank PEMDA Central Bangka for permission to sample of natural fungi in the Pelawan forest

\section{References}

1. Sito E, Istiqomah F, Daniati K et al. (2018) Ekstraksi daun Pelawan (Tristaniopsis merguensis) sebagai antioksidan menggunakan Microwave Asisted Extraction (MAE). Indonesian Journal Pure Application Chemical 1(2): 50-55.

2. Govaerts R, Sobral N, Ashton P et al. (2008) World Checklist of Myrtaceae: 1-455. Kew Publishing, Royal Botanic Gardens, Kew.

3. Souladeth P, Meesawat A (2012) Myrtaceae in Phou Khao Khouay National Protected Area, Lao PDR. Proceeding: 1st ASEAN Plus Three Graduate Research Congress. 927-931.

4. Rahajoe JS, Alhamd L, Atikah TD et al. (2016) Floristic Diversity in the Peatland Ecosystems of Central Kalimantan. In: Osaki M., Tsuji N. (eds) Tropical Peatland Ecosystems. Springer, Tokyo

5. Akbarini D, Iskandar J, Partasasmita R (2017) Collaborative planning for development of the Pelawan Biodiversity Park in Bangka, Indonesia. Biodiversitas 18 (4): 1602-1610.

6. Smith SE, Read DJ (1997) Mycorrhizal symbiosis 2nd. London: Academicac Press.

7. Alexander IJ, Hogberg P (1986) Ectomycorrhizae of tropical angiospermous trees. New Phytologist 102:541-549.

8. Johnson CM, Stout PR, Broyer TC, Carlton AB (1957) Comparative chlorine requirement of different plant species. Plant and Soil 8 (4): 337-353.

9. Liang J, Sun Z, Qu Z et al. (2010) Long-term effect of an ectomycorrhizal inoculum and other treatments on survival and growth of Populus hopeiensis. Forest Ecology and Management 259:2223-2232.

10. Taylor AFS, Alexander I (2005) The ectomycorrhizal symbiosis: life in the real world. Mycologist 19:102-112.

11. Perrier N, Amir H, Colin F (2006) Occurrence of mycorrhizal symbioses in the metal-rich lateritic soils of the Koniambo Massif, New Caledonia. Mycorrhiza 16 (7):449-58.

12. Wenkart S, Roth B, Kagan Z (2001) Mycorrhizal associations between Tuber melanosporum and roots of Cistus incanus. Plant Cell Reports 20: 369-373.

13. Munyanziza E, Kehri HK, Bagyaraj DJ (1997) Agricultural intensification, soil biodiversity and agroecosystem function in the tropics: the role of mycorrhiza in crop and trees. Applied Soil Ecology 6:77-85.
14. Harrison MJ (2005) Signaling in the arbuscular mycorrhizal symbiosis. Annual Review Microbiology 59: 19-42.

15. Li H, Smith SE, Holloway RE et al. (2006) Arbuscular mycorrhizal fungi contribute to phosphorus uptake by wheat grown in a phosphorus-fixing soil even in the absence of positive growth responses. New Phy-tologist. 172 (3): 536-543.

16. Selosse MA, Richard F, He X, Simard SW (2006) My-corrhizal networks: des liaisons dangereuses?. Trends Ecology Evolution 21 (11): 621-628.

17. Smith SE, Smith FA, Jokobsen I (2003) Mycorrhizal fungi can dominate phosphate supply to plants irrespective of growth responses. Plant Physiology 133:16-20.

18. Yang LT, Jiang HX, Tang N, Chen LS (2011) Mechanisms of aluminum-tolerance in two species of citrus: secretion of organic acid anions and immobilization of aluminum by phosphorus in roots. Plant Science180:521-30

19. Schachtman DP, Reid RJ, Ayling SM (1998) Phosphorus uptake by plants: from soil to cell. Plant Physiology 116:447-53.

20. Lynch JP, Ho MD (2005) Rhizoeconomics: carbon costs of phosphorus acquisition. Plant Soil. 269:45-56.

21. Sousa NR, Franco AR, Oliveira RS, Castro PML (2012) Ectomycorrhizal fungi as an alternative to the use of chemical fertilizers in nursery production of Pinus pinaster. Journal of Environment Management 95: S269-S274.

22. Pešková V, Lorenc F, Modlinger R, Pokorná (2015) Impact of droght and stand edge on mycorrhizal density on the fine roots of Norway spruce. Annals of Forest Research. 58(2): 245-257.

23. Schutz W, Milberg P, Lamont BB (2002) Germination requirements and seedling responses to water availability and soil type in four eucalypt species. Acta Oecologia 23:23-30.

24. Yamada A, Ogura T, Ohmasa M (2001) Cultivation of mushrooms of edible ectomycorrhizal fungi associated with Pinus densiflora by in vitro mycorrhizal synthesis. I. Primordium and basidiocarp formation in open-pot culture. Mycorrhiza 1: 59-66.

25. Ushio M, Wagai R, Balser TC, Kitayama K (2008) Variations in the soil microbial community composition of a tropical montane forest ecosystem: Does tree species matter? Soil Biology and Biochemical 40: 2699-2702.

26. Curtis OF, Clark DG (1995) An Introduction to Plant Physiology. New York: Mac Grow Inc.

27. Tawaraya K, Takaya Y, Turjaman M et al. (2003) Arbuscular mycorrhizal colonization of tree species grown in peat swamp forests of Central Kalimantan, Indonesia. Forest Ecology and Management 182: 381-386. 
This page is intentionally left blank. 